\title{
Ponsononowoor
}

2018 , vol. $80,70-80$

http://dx.doi.org/10.12657/denbio.080.007

\author{
Wahbi Jaouadi, Kaouther Mechergui, Mohamed Amine Riahi, \\ Mohamed Larbi Khouja
}

\section{Effect of thinning on Pinus pinea L. development and physico-chemical soil characteristics in northwestern Tunisia: modeling of radial growth under thinning intensity}

Received: 27 July 2018; Accepted: 5 November 2018

\begin{abstract}
In this study, the potential beneficial impacts that the thinnings intensity on stand behavior and soil properties are also studied. This study was designed to test the hypothesis that thinning to various stand densities at young age enhance productivity of wood, cones and the physicochemical characteristics of the soil in Pinus pinea stands. We based our study on four thinning intensity (30, 40, 50 and 65\%) in comparison with the control plot. The study was supplemented by a haracterization of radial growth of trees under the four thinning intensity. It was based on a complete randomized experimental field installed in 1994 in Tabarka forest, in Tunisia. For the radial growth analysis, three cores were taken from 125 trees at a rate of one tree per plot.The study showed that thinning has a significant effect on all dendrometric parameters. They revealed that a thinning intensity of $65 \%$ produces the best wood production (180.710 $\mathrm{m}^{3} / \mathrm{ha}$ ), in annual growth in volume $\left(4.634 \mathrm{~m}^{3} / \mathrm{ha} /\right.$ year) and cone production (1211 cones/ha) compared to other thinning and control plot. Associated vegetation was also influenced by thinning intensities. The physicochemical characteristics of the soil were improved by thinning compared with the control. Significant radial growth thinning was recorde especially in a thinning of $65 \%$ intensity (increases of 3.5 to 6.1 $\mathrm{mm}$ /year) compared to the control (1.1 to $2 \mathrm{~mm}$ /year). A strong relationship between radial growth and age was recorded at Thinning $4\left(\mathrm{R}^{2}=0.923\right)$. These results can be used as an initial basis to refine silviculture of pinion pine in order to improve stand productivity in Tunisia in wood and especially in cones given their importance on the world market.
\end{abstract}

Keywords: Pinion pine, silviculture, thinning intensity, stem volume, radial growth, cones production.

Addresses: W. Jaouadi, The Silvo-Pastoral Institute of Tabarka, BP. n³45, Tabarka 8110, Jendouba University, Tunisia, e-mail: jaouadiwahbi@gmail.com

K. Mechergui, Laboratory of Forest Ecology, National Research Institute of Rural Engineering, Water, and Forestry (INRGREF), University of Tunis Carthage. Rue Hedi Karay B.P.N ${ }^{\circ} 10$ Ariana 2080, Tunisia, e-mail: mecherguikaouther2015@gmail.com

M.A. Riahi, The Silvo-Pastoral Institute of Tabarka, BP. n³45, Tabarka 8110, Jendouba University, Tunisia, e-mail: riahimohamedamin9@gmail.com

M.A. Khouja, Laboratory of Forest Ecology, National Research Institute of Rural Engineering, Water, and Forestry (INRGREF), University of Tunis Carthage. Rue Hedi Karay B.P.N ${ }^{\circ} 10$ Ariana 2080, Tunisia, e-mail: khoujalarbi15@gmail.com 


\section{Introduction}

Called also «umbrella pine» for its typical adulthood, the pine pinion is mainly present on the Mediterranean coastal regions except for the Iberian Peninsula where the species exists under more continental conditions (Adili, 2012). It is known as a multipurpose species. It produces wood for different purposes, its pines are appreciated in many Mediterranean recipes (the species is cultivated for its seeds since antiquity), it produces a resin that provides turpentine used in several industrial estates and has a highly sought-after bark serving for aeration of above-ground composts (Khaldi, 2009). It has also been used for a very long time as an ornamental tree; it runs along the roads, alleys, beaches, gardens etc... The species was cultivated for a long time, that it is sometimes impossible to distinguish between the sites with spontaneous or cultivated stands (Rikli, 1943). The different civilizations that have succeeded each other around the mediterranean sea have cultivated this species (Aloui, 1988). The pinion pine, with its discontinuous and irregular area in the Mediterranean region, has all the characteristics of a species diffused by plantation since Roman times (Agrimi \& Ciancio, 1993). The world total estimated area covered by pinion pine is around 600000 ha $(75 \%$ in Spain, $9 \%$ in Portugal, $8 \%$ in Turkey, $7 \%$ in Italy, $0.5 \%$ in Morocco and the rest in Greece, Lebanon, Tunisia and France (Adili, 2012). In Tunisia, forest formations cover more than 1150000 ha. The Aleppo pine (Pinus halepensis Mill.) is in the first place with 360000 ha, followed by Barbary thuja (Tetraclinis articulata) with 30000 ha and pine pinion (Pinus pinea L.) with 20000 ha (Direction Générale des Forêts (DGF), 2005). In North Tunisia pinion pine presents the first species used in production reforestation. It has been planted in several areas, from Tabarka to El Ghdhabna (Mahdia) through the areas of Nefza, Sejnane, Bizerte and Cape Bon (Aloui, 1988). Although the recent introduction of the species into the reforestation of northern Tunisia and its socio-economic value that has steadily increased, there is very little known on its behavior and productivity in both natural and silvicultural states. The silvicultural scheme for this species has not changed since the first plantings. Planted at high densities, the species is rather treated in Tunisia for wood production, without adaptation to the changing context of the global forest products market. Indeed, the comparison of the revenues provided by pinion pine forests (wood-fruit) shows that it has not been carried out in a methodical way. Although the economic value of the pine trees is becoming more and more important, and can even exceed the value of the woody production (Scarascia-Mugnozza et al., 2000), the management of the pine pinion species has not experienced any real change which can privilege this production. Old plantations were not evaluated to repeat successes and avoid failures, favorable or unfavorable sites for growth and production were known only through poorly supplied literature resulting from work undertaken under other conditions especially in Iberian peninsula. Scientific works on pinion pine in Tunisia are very rare and the references relating to the behavior of the species and its woody and fructiferous productions are few. Our work aims to analyse first the effects of thinnings on the production of pinion pine (in wood and cones) and the physicochemical characteristics of the soil in North West Tunisia and second modeling of the growth.

\section{Material and Methods}

\section{Study area}

The experimental set-up is located in Tabarka pinion pine forest in northwestern Tunisia (Jendouba governorate). This forest series is under the administrative direction of the forest district of Ain Drahem. The area is characterized by a humid climate and it is considered among the most watered zones in Tunisia with a mean rainfall average of $1000 \mathrm{~mm} /$ year mostly provided in winter season. During the months of July and August precipitation is almost non-existent. The average temperature of the hottest month (August) is $25.6{ }^{\circ} \mathrm{C}$ and the average of the coldest month (January) is $11.1{ }^{\circ} \mathrm{C}$. The prevailing winds are from the North. They are often violent and have a remarkable mechanical and physiological action on vegetation.

\section{The experimental field}

The study site was reforested in 1980 by pinion pine with a density of 1111 stems/ha. In order to study the influence of thinning on the species behavior, an experimental field in complete and randomized blocks of five hectares has been installed since 1994 in Tabarka Forest Subdivision. The experimental field is established on a low boulder pine pinion site aged 14 years (reforested in 1980). This device comprises 125 plots (400 $\mathrm{m}^{2}$ each). Each thinning is applied on 25 plots ( $1 \mathrm{ha}$ ) and so are the control ones. In 2018, this stand was 38 years old. Our study will looks to evaluate the influence of thinning on the pine tree stand after 24 years (1994-2018). The trial focused on four intensity levels of thinning compared to the control plots : (i) low intensity where $30 \%$ of trees removed, (ii) moderate intensity where $40 \%$ of trees removed, (iii) high intensity where $50 \%$ of trees removed and (iv) very high intensity where $65 \%$ of the trees removed. In the experimental setup, recordes were taken on 125 plots; diameters (DBH), 
heights, crown diameters in both North-South and East-West directions, basal area and tree volumes. The pinion cones are counted systematically on all trees. An inventory was made in each plot to determine the number of species that are present. For the radial growth analysis, three cores were taken from 125 trees at a rate of one tree per plot. In the laboratory carrots were squeezed and then scanned on a very high resolution A3 format scanner. The annual radial growth was read with Digimizer software. To characterize the effect of thinning on the soil physicochemical parameters, soil samplings were made in each plot at $50 \mathrm{~cm}$ depth. In laboratory moisture content, organic matter and mineral content, carbon, $\mathrm{pH}$ and electrical conductivity were analysed.

\section{Statistical analyzes}

Variance analysis and multiple comparisons of means (Tukey Test) with the $\mathrm{R}^{\circledR}$ statistical program were used to test the effects of thinning on stand growth and productivity. $\mathrm{R}^{\circledR}$ software was used to develop simple tariffs and regression models expressing radial growth as a function of age and applied silviculture. The $\mathrm{R}^{\circledR}$ software was also used to develop main component analysis charts and hierarchical classification by thinning intensities.

\section{Results}

\section{Stand structure and productivity under thinning effect}

The results of variance analysis show that thinning has a significant effect on the pinewood tree girth measurements (Table 1). Thinning 4 has the largest effect on mean diameter $(24.105 \mathrm{~cm} \pm 3.471)$, mean height (11.600 $\mathrm{m} \pm 1.330)$, mean crown diameter North-South $(3.768 \mathrm{~m} \pm 1.204)$ and East-West (4.041 $\mathrm{m} \pm 1.373)$ and the average diameter of the crown (3.983 $\mathrm{m} \pm 1.113)$. Table 2 illustrates the analysis of the variance and the multiple comparison of the means of the dendrometric parameters, the wood production, the cone production and the undergrowth according to the intensity of thinning in comparison with the control. We concluded that applied silvicultural treatments (thinning) have a

Table 1. Analysis of variance and multiple comparison of means (Tukey test) of dendrometric parameters as a function of thinning intensity compared to control in pinion pine stand (Mean \pm Standard deviation)

\begin{tabular}{|c|c|c|c|c|c|c|c|}
\hline $\begin{array}{c}\text { Dendrometric } \\
\text { parameters }\end{array}$ & $\begin{array}{c}\text { Thinning } \\
1\end{array}$ & $\begin{array}{c}\text { Thinning } \\
2\end{array}$ & $\begin{array}{c}\text { Thinning } \\
3\end{array}$ & $\begin{array}{c}\text { Thinning } \\
4\end{array}$ & Control & $\begin{array}{c}\mathrm{F} \\
\text { value }\end{array}$ & $\operatorname{Pr}(>\mathrm{F})$ \\
\hline $\begin{array}{l}\text { Height average at } \\
1.3 \mathrm{~m}(\mathrm{~cm})\end{array}$ & $\begin{array}{c}22.973 \pm 2.813 \\
\text { (b) }\end{array}$ & $\begin{array}{c}23.490 \pm 2.905 \\
\text { (c) }\end{array}$ & $\begin{array}{c}23.464 \pm 2.649 \\
\text { (bc) }\end{array}$ & $\begin{array}{c}24.105 \pm 3.471 \\
\text { (d) }\end{array}$ & $\begin{array}{c}22.552 \pm 3.890 \\
\text { (a) }\end{array}$ & 21.36 & $<2 \mathrm{e}-16^{* *}$ \\
\hline Height average (m) & $\begin{array}{c}11.417 \pm 0.984 \\
\text { (a) }\end{array}$ & $\begin{array}{c}11.451 \pm 0.903 \\
\text { (a) }\end{array}$ & $\begin{array}{c}11.560 \pm 1.077 \\
(\mathrm{ab})\end{array}$ & $\begin{array}{c}11.600 \pm 1.330 \\
\text { (b) }\end{array}$ & $\begin{array}{c}11.371 \pm 0.896 \\
\text { (a) }\end{array}$ & 5.961 & $00000889 *$ \\
\hline $\begin{array}{l}\text { Averag } \\
\text { of crow }\end{array}$ & $\begin{array}{c}3.696 \pm 0.859 \\
\text { (a) }\end{array}$ & $\begin{array}{c}3.778 \pm 0.802 \\
(\mathrm{ab})\end{array}$ & $\begin{array}{c}3.8216 \pm 0.867 \\
(\mathrm{ab})\end{array}$ & $\begin{array}{c}3.925 \pm 1.163 \\
\text { (b) }\end{array}$ & $\begin{array}{c}3.768 \pm 1.204 \\
(\mathrm{ab})\end{array}$ & 3.621 & 0 \\
\hline $\begin{array}{l}\text { Averag } \\
\text { of crow }\end{array}$ & $\begin{array}{c}3.723 \pm 0.912 \\
(\mathrm{ab})\end{array}$ & $\begin{array}{c}3.815 \pm 0.822 \\
\text { (b) }\end{array}$ & $\begin{array}{c}3.801 \pm 0.790 \\
(\mathrm{ab})\end{array}$ & $\begin{array}{l}4.041 \pm 1.373 \\
\text { (c) }\end{array}$ & $\begin{array}{c}3.668 \pm 1.345 \\
\text { (a) }\end{array}$ & 9.098 & 0.000 \\
\hline $\begin{array}{l}\text { Average diameter } \\
\text { of crown }(\mathrm{m})\end{array}$ & $\begin{array}{c}3.710 \pm 0.691 \\
\text { (a) }\end{array}$ & $\begin{array}{c}3.796 \pm 0.635 \\
\text { (a) }\end{array}$ & $\begin{array}{c}3.811 \pm 0.674 \\
\text { (a) }\end{array}$ & $\begin{array}{c}3.983 \pm 1.113 \\
(\mathrm{ab})\end{array}$ & $\begin{array}{c}3.718 \pm 1.130 \\
\text { (b) }\end{array}$ & 7.736 & $0.00000334^{* * *}$ \\
\hline
\end{tabular}

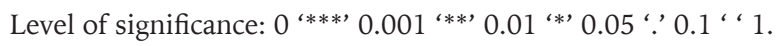

Table 2. Analysis of variance and multiple comparison of means (Tukey Test) of dendrometric parameters, wood production, cone production and plant cover as a function of the intensity of thinning compared with the control in the pinion pine stand (Mean \pm Standard deviation)

\begin{tabular}{|c|c|c|c|c|c|c|c|}
\hline Production/ha ${ }^{-1}$ & Thinning1 & Thinning2 & Thinning3 & Thinning4 & Control & $\begin{array}{c}\mathrm{F} \\
\text { value }\end{array}$ & $\operatorname{Pr}(>F)$ \\
\hline $\begin{array}{l}\text { Total crown } \\
\text { area } \mathrm{m}^{2} / \mathrm{ha}^{-1}\end{array}$ & $\begin{array}{c}3822.503 \\
\pm 1346.245 \\
\text { (b) }\end{array}$ & $\begin{array}{c}5816.814 \\
\pm 1918.933 \\
\text { (c) }\end{array}$ & $\begin{array}{c}6988.129 \\
\pm 2549.751 \\
\text { (d) }\end{array}$ & $\begin{array}{c}10968.903 \\
\pm 7169.68 \\
\text { (e) }\end{array}$ & $\begin{array}{c}2685.183 \\
\pm 1624.932 \\
\text { (a) }\end{array}$ & 410.3 & $<2 \mathrm{e}-16^{* * *}$ \\
\hline $\begin{array}{l}\text { Total basal area } \\
\mathrm{m}^{2} / \mathrm{ha}^{-1}\end{array}$ & $\begin{array}{c}14.229 \pm 3.165 \\
\text { (b) }\end{array}$ & $\begin{array}{c}21.988 \pm 5.381 \\
\text { (c) }\end{array}$ & $\begin{array}{c}26.281 \pm 6.298 \\
(\mathrm{~d})\end{array}$ & $\begin{array}{c}38.030 \pm 13.296 \\
(\mathrm{e})\end{array}$ & $\begin{array}{c}9.311 \pm 2.709 \\
\text { (a) }\end{array}$ & 1219 & $<2 \mathrm{e}-16^{* * *}$ \\
\hline $\begin{array}{l}\text { Total stem vol- } \\
\text { ume } \mathrm{m}^{3} / \mathrm{ha}^{-1}\end{array}$ & $\begin{array}{c}65.190 \pm 17.301 \\
(\mathrm{~b})\end{array}$ & $\begin{array}{c}101.545 \pm \\
29.290 \\
\text { (c) }\end{array}$ & $\begin{array}{c}120.830 \pm \\
33.572 \\
\text { (d) }\end{array}$ & $\begin{array}{c}178.304 \pm 70.952 \\
(\mathrm{e})\end{array}$ & $\begin{array}{c}43.702 \pm 15.173 \\
\text { (a) }\end{array}$ & 949.5 & $<2 \mathrm{e}$ \\
\hline $\begin{array}{l}\text { Number of } \\
\text { cones } / \mathrm{ha}^{-1}\end{array}$ & $\begin{array}{c}398.198 \\
\pm 562.721 \\
\text { (a) }\end{array}$ & $\begin{array}{c}664.917 \\
\pm 920.943 \\
\text { (b) }\end{array}$ & $\begin{array}{c}775.224 \\
+1016.190 \\
\text { (b) }\end{array}$ & $\begin{array}{c}1168.946 \\
\pm 1544.762 \\
\text { (c) }\end{array}$ & $\begin{array}{c}355.784 \\
\pm 391.005 \\
\text { (a) }\end{array}$ & 67.35 & $<2 \mathrm{e}-16^{* * *}$ \\
\hline $\begin{array}{l}\text { Number of } \\
\text { species/ha } \text { ha }^{-1}\end{array}$ & $\begin{array}{c}71.883 \pm 33.110 \\
\text { (b) }\end{array}$ & $\begin{array}{c}112.218 \pm 45.029 \\
\text { (c) }\end{array}$ & $\begin{array}{c}198.018 \pm 24.139 \\
\text { (d) }\end{array}$ & $\begin{array}{c}275.000 \pm 70.960 \\
(\mathrm{e})\end{array}$ & $\begin{array}{c}66.764 \pm 23.555 \\
\text { (a) }\end{array}$ & 3038 & $<2 \mathrm{e}-16^{* * *}$ \\
\hline
\end{tabular}

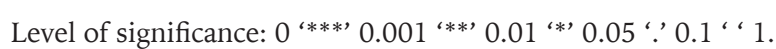




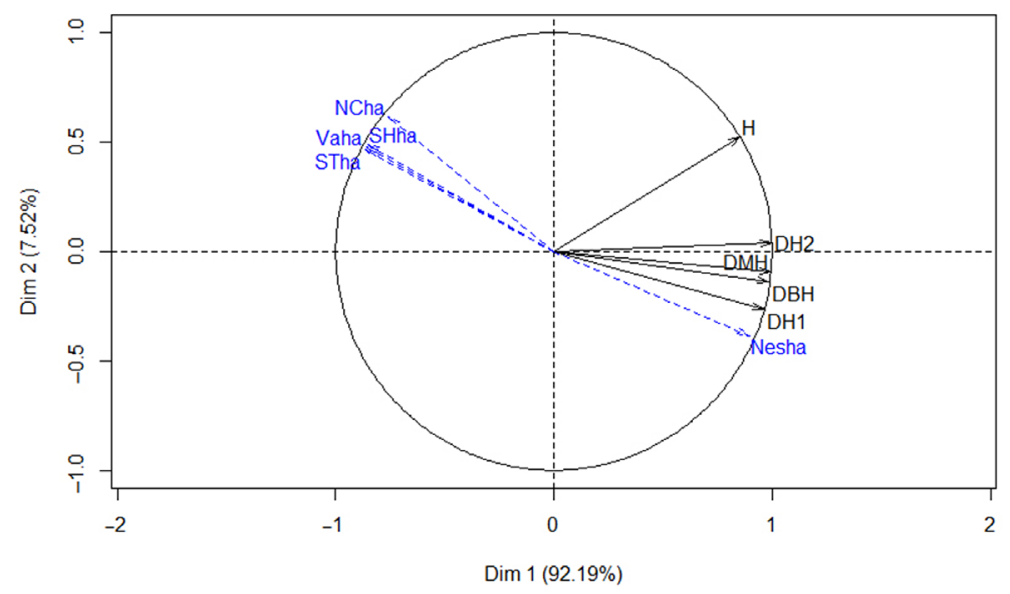

Fig. 1. Principal component analysis, circle of correlation of dendrometric and production variables in the factorial plane $\mathrm{F} 1 \times \mathrm{F} 2$ in the pinion pine under thinnings $(\mathrm{H}$ : tree height, $\mathrm{DBH}$ : diameter of trees at $1.3 \mathrm{~m} \mathrm{DH1}$ : diameter of crown North-South, DH2: diameter of crown East-West, DMH: average diameter of crown, Vaha: stem volume of trees per ha, STha: basal area per ha, SHha: crown area per ha, NCha: number of cones per ha, Nesha: number of species per ha)

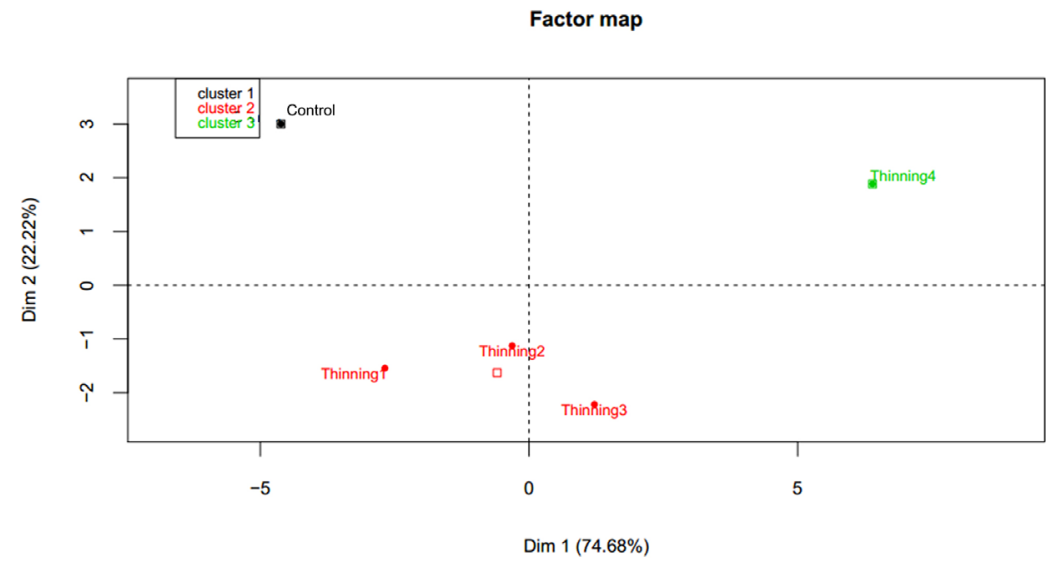

Hierarchical clustering on the factor map

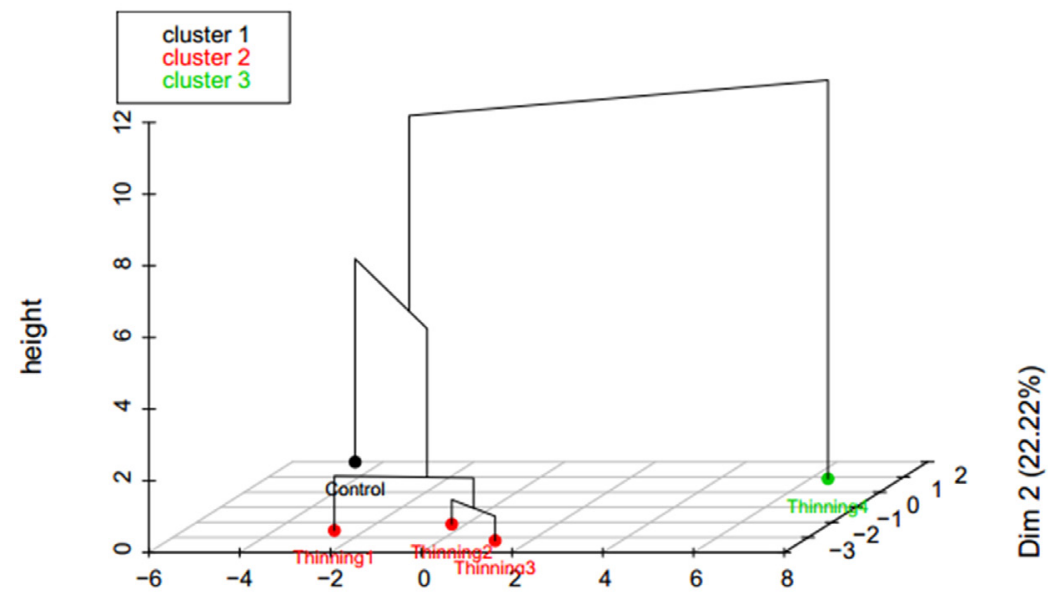

$\operatorname{Dim} 1(74.68 \%)$

Fig. 2. Principal component analysis, distribution and hierarchical classification of thinning in comparison with the control according to the dendrometric and production variables in the factorial plane F1 $\times$ F2 of pinion pine under thinning 


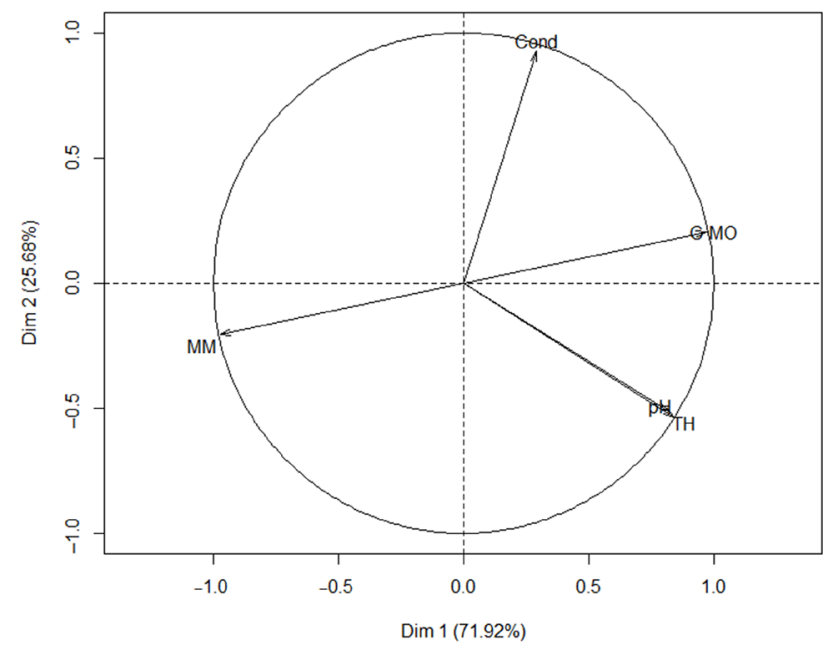

Fig. 3. Principal Component Analysis, circle of correlation of the physico-chemical parameters of the soil in the factorial plane $\mathrm{F} 1 \times \mathrm{F} 2$ in the pinion pine under thinning (MM: organic matter, MM: mineral matter, $\mathrm{pH}$, Cond: Electrical conductivity, TH: moisture content, C: carbon)

significant effect on the parameters studied. Thinning 4 has the most interesting effect on the crown surface $\left(10968.903 \mathrm{~m}^{2} / \mathrm{ha}^{-1}\right)$, the basal area $(9.311$ $\left.\mathrm{m}^{2} / \mathrm{ha}^{-1} \pm 2.709\right)$, the total volume $\left(43.702 \mathrm{~m}^{3} / \mathrm{ha}\right)$. $1 \pm 15,173)$, the number of $\left(355,784\right.$ cones $/ \mathrm{ha}^{-1}$ $\pm 391,005)$ and the number of undergrowth species (66 species $/ \mathrm{ha}^{-1} \pm 23$ ). The correlation circle of the dendrometric variables (Fig. 1) shows that the diameter of the tree is correlated to the diameter of the crown in both geographical directions and the latter is correlated with the present number of under growth species. Thus cone and volume production are correlated with the basal areas and crown surfaces. The main component analysis of the distribution and hierarchical classification show the presence of two groups, the first is formed by thinning 4 and the second group is formed by two subgroups: the control and thinning 1, 2 and 3 (Fig. 2).

\section{Physicochemical characteristics under thinning effect}

Table 3 shows the analysis of the variance and the multiple comparisons of averages of soil physico-chemical parameters as a function of the thinning intensity compared with the control in the pine stand. Soil Physico-chemical parameters (moisture content, percentage of organic matter and mineral matter, electrical conductivity, $\mathrm{pH}$ and carbon content) vary in a highly significant way under thinning effect (<2e-16). Humidity rates from $3.497 \% \pm 0.331$ to $9.900 \% \pm 0.027$ under the effect of thinnings and $3.708 \% \pm 0.089$ for the control. The highest rate of organic matter was recorded under the effect of thinning intensity 4 (Table 3 ). Correlation circle of soil physicochemical parameters under clearing effect shows a negative correlation between organic and mineral matter (Fig. 3). pH and humidity are strongly correlated. The main component analysis of the distribution and hierarchical classification reveals the presence of two groups. The first one consists of the thinning 4 and the second group is made up of two subgroups: the first subgroup includes the control and thinning 1 and the second subgroup consists of thinning 2 and 3 (Fig. 4).

\section{Effect of thinning on radial growth}

The radial growth of pinion pine trees was studied and analyzed to detect its evolution trend in relation to the type of thinning and time. Tree core analysis (125 trees) yielded mean annual radial increment sranging from 1.1 to $6 \mathrm{~mm}$ /year depending on the type of thinning (Fig. 5). The study shows a trend of increasing constant and low annual radial increments between 1980 and 1994 (no thinning) and significant between 1995 and 2018 due to thinning in 1994 especially for thinning 4 compared to the control. This increase will continue in the future which is a beneficial effect for pine forest pinion. The development of the relation

Table 3. Analysis of variance and multiple comparison of means (Tukey's test) of physico-chemical soil parameters as a function of thinning intensity compared to control in pine stand (Mean \pm Standard deviation).

\begin{tabular}{|c|c|c|c|c|c|c|c|}
\hline Soil characteristics & Thinning1 & Thinning2 & Thinning3 & Thinning4 & Control & F value & $\operatorname{Pr}(>F)$ \\
\hline Humidity rate (\%) & $\begin{array}{c}3.497 \pm 0.331 \\
\text { (a) }\end{array}$ & $\begin{array}{c}4.526 \pm 0.231 \\
\text { (b) }\end{array}$ & $\begin{array}{c}6.4540 \pm 0.297 \\
\text { (c) }\end{array}$ & $\begin{array}{c}9.900 \pm 0.027 \\
\text { (d) }\end{array}$ & $\begin{array}{c}3.7088 \pm 0.089 \\
\text { (a) }\end{array}$ & 1363 & $<2 \mathrm{e}-16^{* * *}$ \\
\hline Organic matter (\%) & $\begin{array}{c}4.097 \pm 0.126 \\
(\mathrm{ab})\end{array}$ & $\begin{array}{c}4.265 \pm 0.650 \\
(\mathrm{ab})\end{array}$ & $\begin{array}{c}3.650 \pm 0.590 \\
\text { (a) }\end{array}$ & $\begin{array}{c}7.410 \pm 0.439 \\
\text { (c) }\end{array}$ & $\begin{array}{c}4.608 \pm 0.820 \\
\text { (b) }\end{array}$ & 67.65 & $<2 \mathrm{e}-16^{* * *}$ \\
\hline Minera & $\begin{array}{l}95.903 \pm 0.126 \\
(\mathrm{bc})\end{array}$ & $\begin{array}{c}95.735 \pm 0.650 \\
\text { (bc) }\end{array}$ & $\begin{array}{c}96.350 \pm 0.590 \\
\text { (c) }\end{array}$ & $\begin{array}{l}92.590 \pm 0.439 \\
\text { (a) }\end{array}$ & $\begin{array}{l}95.392 \pm 0.820 \\
\text { (b) }\end{array}$ & 67.65 & $<2$ \\
\hline $\begin{array}{l}\text { Electrical conductiv- } \\
\text { ity }(\mu \mathrm{s})\end{array}$ & $\begin{array}{c}28.26 \pm 3.816 \\
\text { (a) }\end{array}$ & $\begin{array}{c}26.06 \pm 3.951 \\
\text { (a) }\end{array}$ & $\begin{array}{c}25.88 \pm 5.352 \\
\text { (a) }\end{array}$ & $\begin{array}{c}25.06 \pm 1.928 \\
\text { (a) }\end{array}$ & $\begin{array}{c}25.64 \pm 2.440 \\
\text { (a) }\end{array}$ & 1.091 & $<2 \mathrm{e}-16^{* * *}$ \\
\hline $\mathrm{pH}$ & $\begin{array}{c}5.125 \pm 0.007 \\
\text { (a) }\end{array}$ & $\begin{array}{c}5.621 \pm 0.024 \\
\text { (c) }\end{array}$ & $\begin{array}{c}5.730 \pm 0.018 \\
\text { (d) }\end{array}$ & $\begin{array}{c}6.398 \pm 0.059 \\
(\mathrm{e})\end{array}$ & $\begin{array}{c}5.330 \pm 0.013 \\
\text { (b) }\end{array}$ & 2488 & $<2 \mathrm{e}-16^{* * *}$ \\
\hline Carbon (\%) & $\begin{array}{c}2.375 \pm 0.0715 \\
(\mathrm{ab})\end{array}$ & $\begin{array}{c}2.475 \pm 0.376 \\
(\mathrm{ab})\end{array}$ & $\begin{array}{c}2.117 \pm 0.342 \\
\text { (a) }\end{array}$ & $\begin{array}{c}4.298 \pm 0.256 \\
\text { (c) }\end{array}$ & $\begin{array}{c}2.672 \pm 0.475 \\
\text { (b) }\end{array}$ & 67.68 & $-16^{* * *}$ \\
\hline
\end{tabular}

Level of signification: 0 (***) $0.001^{(* *)} 0.01^{\text {**’ }} 0.05$ '? $0.1^{\prime \prime \prime} 1$. 


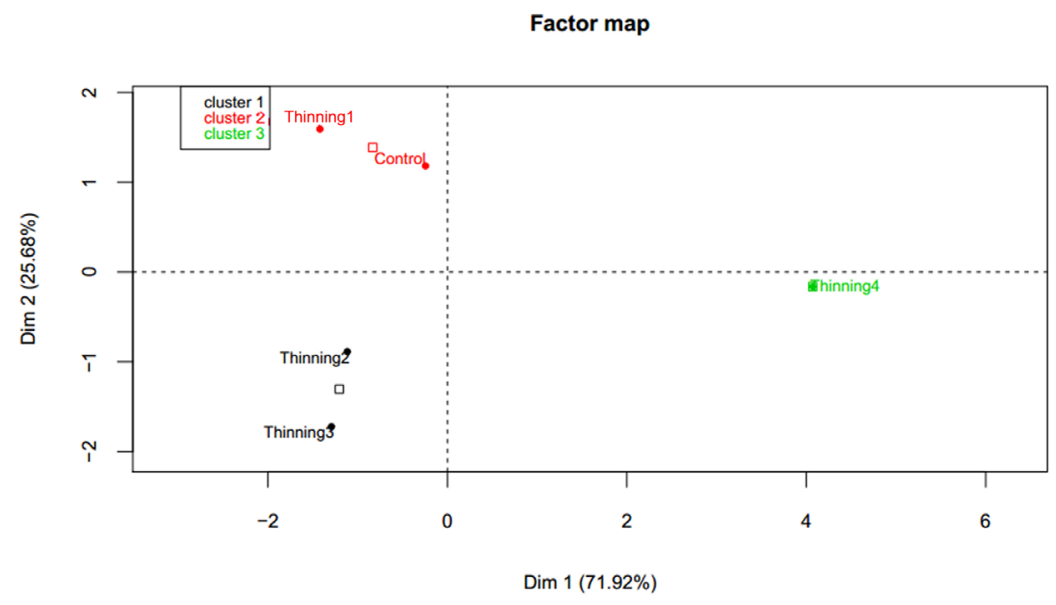

Hierarchical clustering on the factor map

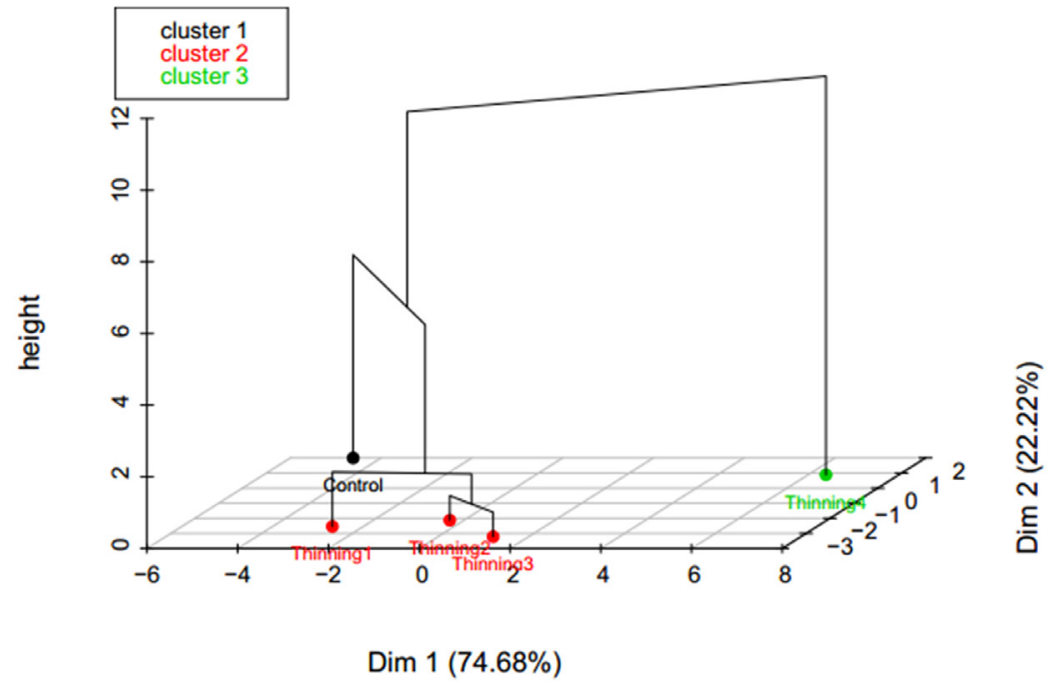

Fig. 4. Principal component analysis, distribution and hierarchical classification of thinning intensities in comparison with the control according to physico-chemical soil parameters in the F1 $\times$ F2 factorial plane in the pinion pine

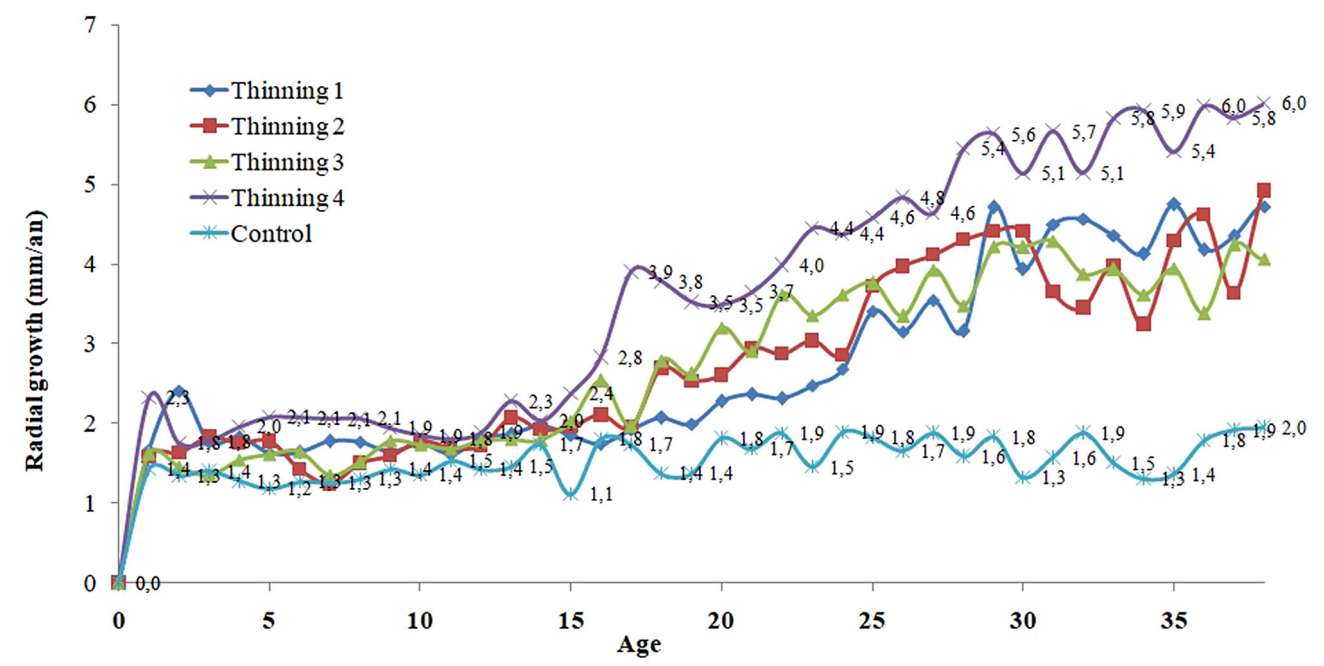

Fig. 5. The trend in the evolution of radial growth (mm/an) under Thinning (Thinning 1: thinning intensity is $30 \%$, Thinning 2: thinning intensity is $40 \%$, Thinning 3 : thinning intensity is $50 \%$, Thinning 4 : thinning intensity is $65 \%$, C: control plots) 


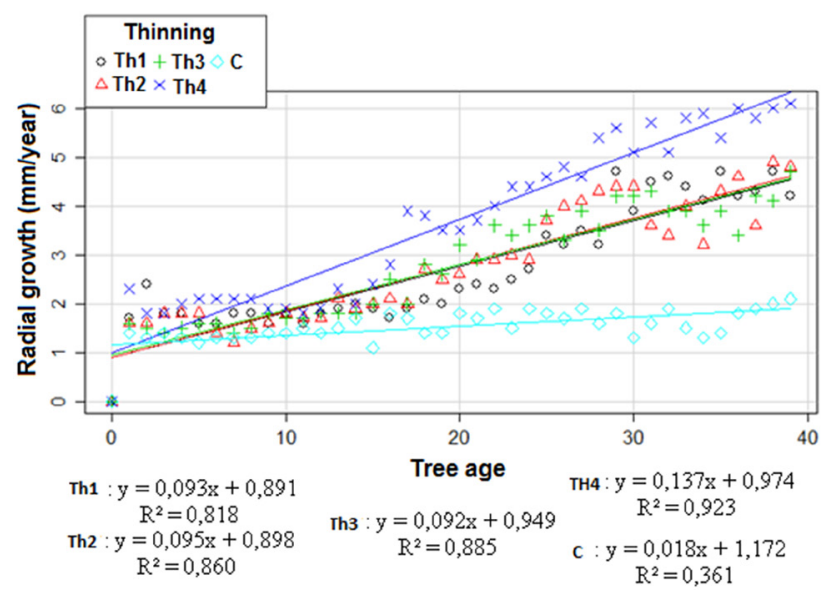

Fig. 6. Relationship between radial growth and stand age under thinnings in the pinion pine (Th1: thinning intensity $30 \%$, Th2: thinning intensity $40 \%$, Th3: thinning intensity 50\%, Th4: thinning intensity $65 \%, \mathrm{C}$ : control plots

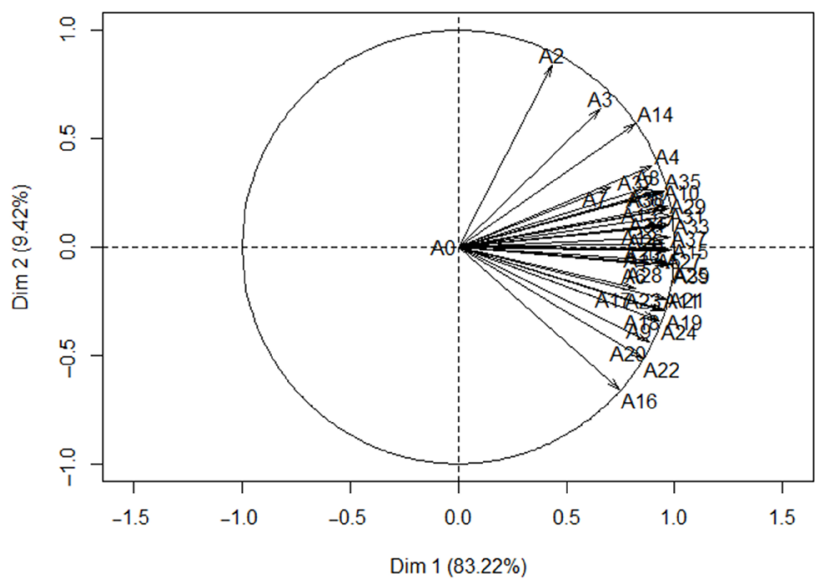

Fig. 7. Principal Component Analysis, correlation circle of annual average radial growth of the stand (A0: 0 years, A1: one year, A2: two years ... to $38: 38$ years) in the factorial plane $\mathrm{F} 1 \times \mathrm{F} 2$ in the pinion pine under the thinning
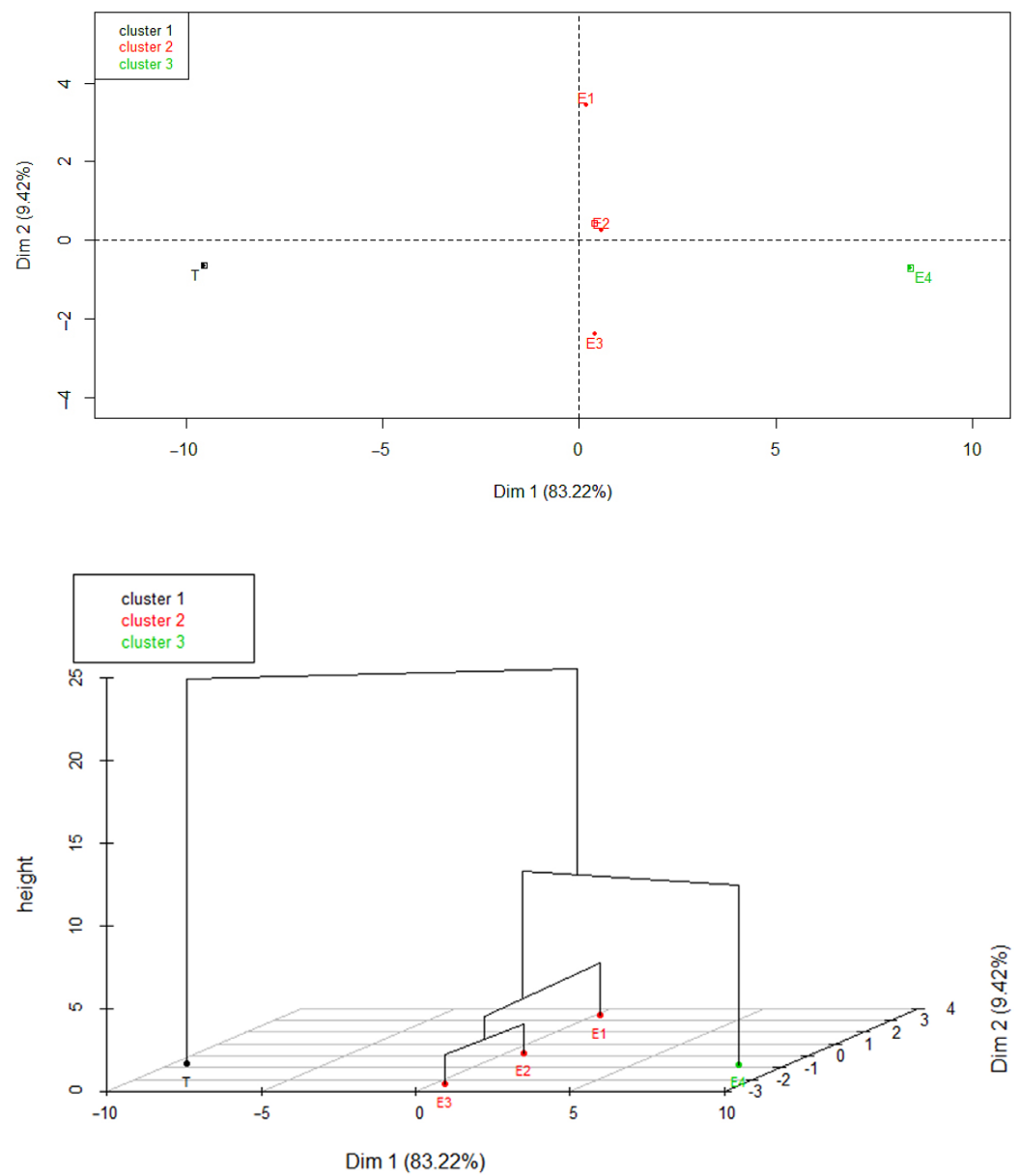

Fig. 8. principal component analysis, distribution and hierarchical classification of thinning intensities compared with the control plot according annual mean radial growths in the F1 $\times$ F2 factorial plane in the pinion pine (E1 : Thinning 1, E2 : Thinning 2, E3 : Thinning 3, E4 : Thinning 4, T : Control plot) 
ship between annual mean radial increments and stand age under thinning is recorded in Fig. 6. Simple regression gave us the highest coefficient of determination for thinning $4\left(\mathrm{R}^{2}=0.943\right)$. The correlation circle of the stand annual radial mean growth under thinning shows a significant correlation between years (Fig. 7). The main component analysis of the distribution and the hierarchical classification shows a presence of two groups, the first consisting of the control and the second one is made up of two subgroups: the first subgroup is formed by the thinning 4 and the second subgroup consists of thinning 1, 2 and 3 (Fig. 8).

\section{Discussion}

According to Tunisia's forest inventory carried out in the north-west of the country in 2010 (DGF, 2010), the average volume of timber and pine pinion growth are respectively $37.83 \mathrm{~m} 3 / \mathrm{ha}$ and $1.342 \mathrm{~m} 3$ / ha/year in Jendouba and $84.205 \mathrm{~m} 3 /$ ha and 1.037 $\mathrm{m} 3 /$ ha/year in Beja. In northern Tunisia, they are of $44.034 \mathrm{~m} 3 / \mathrm{ha}$ and $1.177 \mathrm{~m} 3 / \mathrm{ha} /$ year in Bizerte. In the North-East, they are $29.752 \mathrm{~m} 3 /$ ha and 0.859 $\mathrm{m} 3 / \mathrm{ha} /$ year in Nabeul (Cap Bon). In Barbara (Governorate of Siliana) they are $37.8 \mathrm{~m} 3 /$ ha and 1.34 m3/ha/year (La Societate des Sciences Naturelles de Tunisie (SSNT), 2012). The results of our study on the growth of the pinion pine stand in Mekna I show that the trees have a diameter at breast height (DBH) which varies between 10 and $40 \mathrm{~cm}$ with an average diameter of $23.14 \mathrm{~cm}$. In this sense Adili (2012) in a study on growth, fruiting and natural regeneration of artificial stands of pine pine (pinus pinea L.) in northern Tunisia found that trees in Mekna III have a diameter (DBH) which varies between 6.5 and $61 \mathrm{~cm}$ between 5 to $57 \mathrm{~cm}$ in Ouchtata II and between 5 and $47 \mathrm{~cm}$ in Bechateur. These results indicate that pinewood forests in the northwestern regions have nearly the same dendrometric characteristics and were reforested almost at the same date. Regarding the basal area, Adili (2012) has shown that it varies from 25.6 $\mathrm{m} /$ ha to Mekna III, $24.8 \mathrm{~m}^{2} /$ ha to Ouchtata II and $31.7 \mathrm{~m}^{2} /$ ha to Bechateur. Our results show that, depending on the type of thinning, stand trees have basal areas ranging from 9.2 to $38.4 \mathrm{~m}^{2} /$ ha. Adili (2012) showed that the older and less dense the stand, the greater the development of the crown and vice versa. It confirms the negative effect of density on crown development. Indeed, it is accepted that the growth and expansion of the crown is subject to competition, more and more important depending on the density of neighboring trees, for space and therefore for light (Zhang et al., 2002). A low density of individuals favors the interception of light and the growth of trees in diameter as is the case of thinning 1, 2, 3 and 4 , while a high density of individuals (the control site), accentuates the phenomenon of competition and slows the growth in diameter of the trees. Adili (2012) confirmed that, despite the equal age of pine stands, the evolution of dendrometric parameters is not the same, which is explained by the variability of the density factor. These results are consistent with the evolution of the basal area with Chen (1997) for the evolution of the recovery rate, which increases with densities. Our results revealed that the stand is responding favorably to intensive thinning. These results show that increases and production in wood are significantly influenced by the intensity of the thinning. The same results were found by Khaldi (2009). We can say that this type of test responds, in part, to specific questions from managers regarding silvicultural interventions in pine plantations. In fact, the higher the density, the smaller the diameter growth, the height and the basal area. However, if this density is lower, increments and wood production increases. In addition to the increase in radial growth, intensive thinning can lead to better resistance of trees to water stress. This statement, valid for maritime pine in the Mediterranean Landes in France (Timbal, 2002). It was proved that strong thinnings allowed, of course, a better radial growth, but also a better resistance of the trees to the water stress even if, during years of strong drought, these intensive thinnings were not enough to prevent a significant reduction in radial growth. This result leads us to take into account this better resistance to water stress, especially with the identification of increasingly clear trends (climatic changes observed during the last decades). El Khorchani et al. (2007) conclude, after having tested a radial growth relationship model-three pines hydric balance in Tunisia (including the pine pinion) that it was possible to distinguish between dry years and wet years by integrating the water capacity of the soil, albedo and the effect of remanence, during the period 1978-2001, a net increase in drought resulted in the appearance of thin rings. In Spain, the experimentation of different thinning intensity on Scots pine showed that the total volume and the increase in volume decreased with the intensity of thinning and that no difference was found between treatments or for the total basal area or growth rate. The response in terms of diameter increase due to thinning was stronger for young trees (less than 50 years old) and medium-sized trees Khaldi (2009). To understand the structure and dynamics of forest stands, the study of the (allometric) relations between some dendrometric parameters such as the DBH and the volume to achieve a cubic model tree has necessary. Relationships between these parameters taken in pairs according to the type of thinning are good indicators of the ecological conditions of growth of the species (Gnangle, 2005). The relationships established in current study show that diameter is a highly 
predictive variable in the wood production of a forest stand, as is often the case for even-aged stands where tree growth is fairly homogeneous throughout their life. For this reason it has always been considered as an important criterion used in the management and silviculture of this type of settlement (Chabaud \& Nicolas, 2009). At equal age, annual radial growth showed variability between different types of thinning compared with the control. In fact, this growth remains greater in the stand that has undergone a silvicultural treatment, it becomes more and more important in the thinning 4 with the high intensity. This difference in annual growth between these stands could be attributed to soil fertility. However, the soil analyzes of the plots considered have shown that they are very poor in organic matter. In Tunisia, the Pinion Pine is distributed mainly in the Dar Chichou (Cap Bon), Sejenane, Bizerte, Tabarka and Ain Draham regions, half of which are in seed production (over 30 years of age). The other stands are still young (under 20 years). In Tunisia, the production of pine nuts was not considered as a production objective of the plantations. The fruiting of the pinion pine starts around 15 to 20 years, with an abundant production cycle every 3 to 4 years. The pines are very popular in domestic market given its important use in quality pastries. The valuation of this product of interesting prospects for pinion pine plantations, which are increasing every year. The national potential for pine production could reach 160 tonnes/ year, with an average production of $200 \mathrm{~kg}$ cones/ha/ year, equivalent to $40 \mathrm{~kg}$ of seed or $8 \mathrm{~kg}$ of pine/ha/ year (Office de Developpement du Nord-Ouest (ODNO), 2004). In this context there is, however, a major problem that has been engendered by this economic importance of the pine, it is the harvest carried out in crime, long before the maturity of the cones. This is likely to reduce its potential due to the loss of weight of the immature pines and the deterioration of the quality of this product. In Siliana, production is estimated at $300 \mathrm{~kg}$ cones/ha (SSNT, 2012). Intensive thinnings have been an important factor in increasing fruiting. In this study, we have shown that cone production is very low in the whole stand because of the illegal harvesting of cones by delinquents, ranging from 360 to 1211 cones/ha, confirmed by Adili (2012) who indicated the average production of pine stand cones in the north-west is 1964 cones/ha and also confirmed by Khaldi (2009). If we compare the number of cones in our study (1.3 cones on average/tree average age of 38 years old) and the Adili's 2012 study (5.6 cones on average/ tree, 35 years old) and to that of the study lead by Ganatsas et al. (2008) on mature pine stands with mean age greater than 120 years $(9.8$ cones/tree for a closed mature stand and 62.7 cones/tree for an open mature stand), the age corresponding to the decline fruit production that starts from 80 years, we note that the production at the level of our stand is very low despite its age (38 years) which corresponds to the best productivity period of the species. The relationships established in our study between the age of pine pines and the radial trunk growth at $1.30 \mathrm{~m}$, show that age is a highly predictive variable of diameter growth, as is often the case with even-aged stands where tree growth is fairly homogeneous throughout their life. At equal age, annual radial growth showed variability between the control and silvicultural treatments. In fact, this growth remains greater in the treated stands, it becomes more and more important when the intensity of thinning increases. Adili (2012) found that the difference in annual radial growth between stands of the same age and density could be attributed to soil fertility. However, the soil analyzes of the sites considered have shown that all three are of very basic type (high $\mathrm{C} / \mathrm{N}$, low organic matter content, low cation exchange capacity...). The effect of age on growth may be important during the early years of life. Pinus stands that have high radial growth rates. These high rates are only influenced by competition from shrubs and under vegetation because of their light-related behavior. However, competition in planted pine forests is not as strong as in naturally regenerating pines (Mazza \& Manetti, 2013). Bouachir et al. (2017) confirm that with increasingly severe environmental conditions, negatively influences wood production through slow radial growth. This could be the case for the trees of our study in the control site, where the frequency of small rings is increased. It can be associated with an increase in water stress, expressed by the low humidity rate in our study, which could be of climatic origin (dry years) or of edaphic origin (sandy soils of the coastal dunes). El Khorchani et al. (2007) found a correlation between the increase in drought and the appearance of reduced rings in the period 1978-2001 compared to the period 1954-1977. De Luis et al. (2009; 2010) have shown that the first potential cause of an observed increase in missing rings could be related to increased stress conditions due to rising temperatures and decreasing rainfall recorded in Spanish Mediterranean areas since 1970. Further dendrochronological studies of Pinus pinea and Pinus halepensis in semi-arid coastal sand dunes in southeastern Spain have shown a high frequency of missing rings in recent years due to drought and other factors disturbances such as sea spray (Raventos et al., 2001; Novak et al., 2011). As reported in other parts of the Mediterranean coast in Spain (Raventos et al., 2001) and Italy (Bussotti et al., 1995; 1997), the appearance of rings may accompany alteration or death of needles, decreased photosynthetic production and reduced availability of assimilates for wood production (Raddi et al., 2009). Bouachir et al. 
(2017) suggest that stands growing under stress require silvicultural interventions to achieve sustainability and good growth.

\section{Conclusion}

Pinion pine in Tunisia is not studied in terms of silvicultural management and the factors that determine it. As a result, the silvicultural route for this species has not changed since the first plantings and is oriented only towards wood production, without any adaptation to the changing context of the global forest products market context that highlights the economic value of pine nuts exceeding wood production. The results of this study show that silvicultural treatment by thinning is the main factor controlling the growth and production of trees, however the availability of water, light and nutrients are necessary for their subsequent growth. In this sense, the strong thinnings (65\%) significantly increased the radial growth and the volume of the trees ha as well as the physicochemical characteristics of the soil. Our study provides important information that will serve as a basis for managers in the context of improving growth, fruit production and site preparation for better management of pine stands. A need to create other experimental devices by varying the age, the silvicultural practices (pruning and other) and taking into account two important factors of pine forest in Tunisia: overgrazing and illegal harvesting of cones and trying to control them with defenses and fences in order to have a solid base to provide managers with an adequate and long-term management plan. Finally, our study will serve as a first base to help foresters establish better management, including thinning, to improve the growth of these stands.

\section{References}

Adili B (2012) Croissance, fructification et régénération naturelle des peuplements artificiels de Pin pignon Pinus pinea L. au Nord de la Tunisie. Thèse doctorat en sciences agricoles. Université Blaise Pascal - Clermont-Ferrand II.

Agrimi M \& Ciancio O (1993) Le pin pignon (Pinus pinea L.). Comité des questions forestières méditerranéennes. Silva Mediterranea. Organisation des Nations Unies pour l'alimentation et l'agriculture.

Aloui A (1988) Sylviculture du Pin pignon en Tunisie. FAO-Silva Mediterranea. Institut Sylvo-Pastoral de Tabarka.

Bouachir BB, Khorchani A, Guibal F, El Aouni MH \& Khaldi A (2017) Dendroecological study' of Pinus halepensis and Pinus pinea in northeast coastal dunes in Tunisia according to distance from the shoreline and dieback intensity. Dendrochronologia 45: 62-72. doi:10.1016/j.dendro.2017.06.008.

Bussotti F, Bottacci A, Grossoni P, Mori B \& Tani C (1997) Cytological and structural changes in $\mathrm{Pi}$ nus pinea $\mathrm{L}$. needles following the application of an anionic surfactant. Plant, Cell And Environment 20: 513-520. doi:10.1046/j.1365-3040.1997.d0191.x.

Bussotti F, Grossoni P \& Pantani F (1995) The role of marine salt and surfactants in the decline of Tyrrhenian coastal vegetation in Italy. Annales des Sciences Forestieres 52: 251-261. doi:10.1051/ forest:19950306.

Chabaud L \& Nicolas L (2009) Pineraies des plaines $\mathrm{du}$ Centre et du Nord-Ouest. Office National des Forêts, Paris.

Chen HYH (1997) Interspecific responses of planted seedlings to light availability in interior British Columbia, survival, growth, allometric patterns, and specific leaf area. Canadian Journal of Forest Research 27: 1383-1393. doi:10.1139/x97-099.

De Luis M, Brunetti M, Gonzalez-Hidalgo JC, Longares, LA \& Martin-Vide J (2010) Changes in seasonal precipitation in the Iberian Peninsula during 1946-2005. Global and Planetary Change 74: 27-33. doi:10.1016/j.gloplacha.2010.06.006.

De Luis M, González-Hidalgo JC, Longares LA \& Stepanek P (2009) Seasonal precipitation trends in the Mediterranean lberian Peninula in second half of $20^{\text {th }}$ century. International Journal of Climatology 29: 1312-1323. doi:10.1002/joc.1778.

Direction Générale des Forêts (DGF) (2010) Inventaire National de Tunisie. Deuxième inventaire national forestier et pastoral. Ministère de l'Agriculture de Tunis.

El Khorchani A, Gadbin-Henry C, Bouzid S \& Khaldi A (2007) Impact de la sécheresse sur la croissance de trois espèces forestières en Tunisie (Pinus halepensis Mill., Pinus pinea L. et Pinus pinaster Sol.). Sécheresse 18: 113-121.

Ganatsas P, Tsakaldimi M \& Thanos C (2008) Seed and cone diversity and seed germination of Pinus pinea in Stofylia site of the Natura 2000 Network. Biodiversity and Conservation 17: 2427-2439. doi:10.1007/s10531-008-9390-8 17: 2427-2439.

Gnangle PC (2005) Parcs à Karité (Vitellaria paradoxa) (Gaertn. C.f.) (Sapotaceae) au Benin: importance socio-culturelle, caractérisations morphologique, structurale et régénération naturelle. Diplôme d'études approfondies en aménagement et gestion des ressources naturelles. Agro-foresterie, Université d'Abomey-Calavi, Bénin.

Khaldi A (2009) Etude de la croissance et des productions du Pin pignon (Pinus pinea L.) en relation avec les facteurs écologiques, sylvicoles et génétiques en Tunisie. Thèse de doctorat en sciences 
agronomiques. Institut National Agronomique de Tunisie, Université de Carthage.

La Societate des Sciences Naturelles de Tunisie (SSNT) (2012) Evaluation économique des biens et services des forêts tunisiennes. Rapport final (ed. by H Daly, L Croitoru, K Tounsi, A Aloui \& S Jebari) Ministère de l'environnement en Tunisie.

Mazza G \& Manetti MC (2013) Growth rate and climate responses of Pinus pinea L. in Italian coastal stands over the last centry. Climatic Change 121: 713-725. doi:10.1007/s10584-013-0933-y.

Novak K, De Luis M, Cufar K \& Raventos J (2011) Frequency and variability of missing tree rings along the stems of Pinus halepensis and Pinus pinea from a semiarid site in SE Spain. Journal of Arid Land 75: 494-498. doi:10.1016/j.jaridenv.2010.12.005.

Office de Developpement du Nord-Ouest (ODNO) (2004) Valorisation des produits forestiers au Nord-Ouest. Ministère du Développement et de la Coopération Internationale en Tunisie.

Raddi S, Cherubini P, Lauteri M \& Magnani F (2009) The impact of sea erosion on coastal Pinus pinea stands: A diachronic analysis combining treerings and ecological markers. Forest Ecology And Management 257: 773-781. doi:10.1016/j.foreco.2008.09.025.
Raventos J, De Luis M, Gras MJ, Cufar K, Gonzalez-Hidago JC, Bonet A \& Sánchez JR (2001) Growth of Pinus pinea and Pinus halepensis as affected by dryness, marine spray and land use changes in a Mediterranean semiarid ecosystem. Dendrochronologia 19: 211-220.

Rikli M (1943) Das Pflanzenkleid der Mittelmeerländer. Huber, Berne, 148 p.

Scarascia-Mugnozza G, Oswald H, Piussi P \& Radoglou K (2000) Forests of the Mediterranean region: gaps in knowledge and research needs. Forest Ecology and Management 132: 97-109. doi:10.1016/S0378-1127(00)00382-0.

Timbal J (2002) Analyse rétrospective de la croissance radiale et mise en relation avec le bilan hydrique dans un dispositif d'intensité d'éclaircie de pin maritime dans les Landes de Gascogne. Annals of Forest Science 59: 205-217. doi:10.1051/ forest:2002008.

Zhang SY, Chauret G, Ren HQQ \& Desjardins R (2002) Impact of initial spacing on plantation black spruce lumber grade yield, bending properties, and MSR yield. Wood and Fiber Science 34: 460-475. 